\title{
The compositional and functional study of the Liv fishermen's homesteads
}

\author{
Dace Ržepicka, Aija Ziemeḷniece, Latvia University of Agriculture
}

\begin{abstract}
The clusters of the homesteads of the old Liv fishermen from Cape Kolka to Staldzene keep only some of the mosaic grains from the pride and glory of fishermen's homes which existed until the war. In the $30 \mathrm{~s}$ of the $\mathbf{2 0}^{\text {th }}$ century, the farming and everyday life of the coastal people is marked only by separate outhouses - the cattle-shed, fishing net, boat and firewood sheds, smokehouses, cellars. They are witnessing the bygone farming by the sea as the boats, fishing nets, plank-ways, and people who have the skill to take a boat offshore have disappeared. Today, it is difficult to name settlements as the Liv villages because the number of the disappeared homesteads and lost people in the last 50 years is so huge that it can only be considered as a distant reflection of the situation it was until 1940. Today, this coastline is functioning as an open-air museum, in which the recreation and tourism industry is developing. Only a rare fishing boat slides into the sea at night, landing the fishing nets and collecting them in the morning, so maintaining a still alive skill in fishing and fish processing. Thanks to today's rigorous legislation, small fragments of the historical tradition of farming and building are being slowly recovered. By studying them during the expedition, there is an opportunity to get information about the compositional and functional criteria of the old fishermen's homesteads.
\end{abstract}

Keywords: building structure, compositional solution, cultural and historical heritage, coloring, structure

\section{Introduction}

The geographically and economically attractive coastline from Kolka to Staldzene has tempted the political greed of the combatant countries of the early phase of the $20^{\text {th }}$ century, bringing with them the devastations of the two world wars and wiping out the dwelling places of fishermen, carefully built through centuries that told of the Liv management manners and development already from the $14^{\text {th }}$ century.

The next devastating blow to the historical coastal location was given by the Soviet time. With the arrival of collectivization in the 50s of the $20^{\text {th }}$ century and the foundation of fishermen's artels, the usual farming character changed. This is readable in the construction of large-size boats and fishing net sheds (Mazirbe), in the change of the width of road and transport areas along fences (Sìkrags), in the tree clusters in places where even before the war there have been places of dwellings. Only the Sīkrags, Ovīši, and Miķeḷbāka lighthouses proudly stand against the storm and the processes of the political wave rolling. In the $60 \mathrm{~s}$ of the $20^{\text {th }}$ century, collectivization is followed by establishing of the Soviet military bases with the building of underground concrete bunkers in the dunes, bringing with them the ban for fishermen to proceed to sea. Thereby, the historical fishing farm keeping came to an end.

The early $21^{\text {st }}$ century is characterized by the home care to save the remaining and exposing the new to the historic building traditions. Thanks to today's strict laws, each historical place of dwelling is very carefully detailed within the architectural and compositional requirements. After the wave of the war and collectivization, the remaining homesteads create a strange spacing of the historical building. The empty spaces are filled with tree clusters and meadows, so misleading about the former building density, the number of the population, and fishing effort.

After the expedition and categorization of the archival research materials, the research aims to collect the criteria of the historic landscape space and the architectural and compositional structure of outhouses.

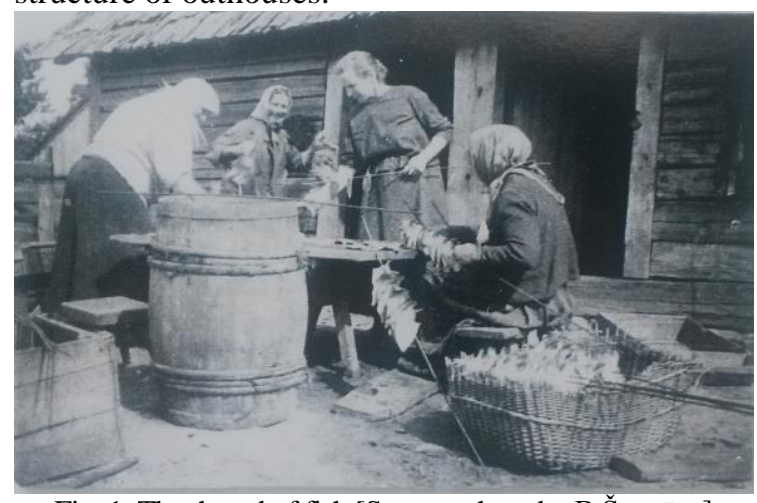

Fig. 1. The thread of fish [Source: photo by B.Suvcāne]

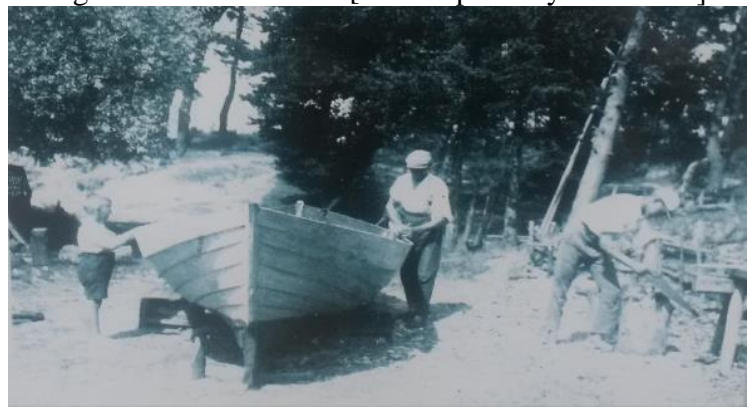

Fig. 2. Construction of boat [Source: photo by. B.Šuvcāne] 
For the assessment of the transformation processes of the coastal fishing villages, several research assignments are to be defined:

- the study of the structure of fishing villages;

- the description of buildings of fishermen's homesteads;

- the position of the old outhouses in the yard.

The summary of the research material is based on the comparative method, using archival materials, obtained from monographs, publications, and interviews with local residents.

\section{Materials and Methods}

From the $14^{\text {th }}$ century, the settlements of Livs on the northern coast of Kurzeme are characterized by the originality of the landscape space, which is not only based on the fishing activity as a functional aspect but also on the peculiarities of the structure of building of places of dwelling. Homesteads as separate small living spaces at the same time served as "production zones" when handling fish, building boats, preparing the lumber, weaving fishing nets. This contributed to a continuous creation of the production area along the coastline, which rapidly expanded in the $20 \mathrm{~s}$ of the $20^{\text {th }}$ century. With a gradual development of craft skills in the making of rowing boats, their number, quantity, and the recognition of good fishing locations increased. Overall, this contributed to increasing of the location of fishermen's farmsteads together. The nature of the fishery is based on the hard conditions of physical work, which is impossible to do by one person - to keep flat the boat in waves, to land fishing nets and to collect the fishing nets or seines and to row. This work requires several men. So, historically, the nature of fishery is reflected in the compositional building structure.

In Europe, at the turn of the $19^{\text {th }}$ and $20^{\text {th }}$ centuries, the boom of the industrial revolution also brought with it the development of the northern coast of Kurzeme. As a bright feature of the Liv villages, 2 aspects of the economic growth are to be mentioned:

in the $20 \mathrm{~s}-30 \mathrm{~s}$ of the $20^{\text {th }}$ century, rowing boats gradually were replaced by motorboats, able to enter deeper into the sea, fishing for about 14-20 km away from the coast (9). It increased catches and the quantity of fish processing, and the need to build ice houses for fish keeping;

the economic boom of the Liv villages was facilitated by the little train line built in 1916, connecting the seaside villages with Ventspils, Dundaga, Talsi, Stende. The highway from the coast to Dundaga served for the fishermen as a good trade route in the inland direction.

Based on the above aspects, it is vividly accompanied by the fishermen's cooperative of the region of Kolka established in the 30s of the 20th century, formed by 9 departments, covering a $60 \mathrm{~km}$

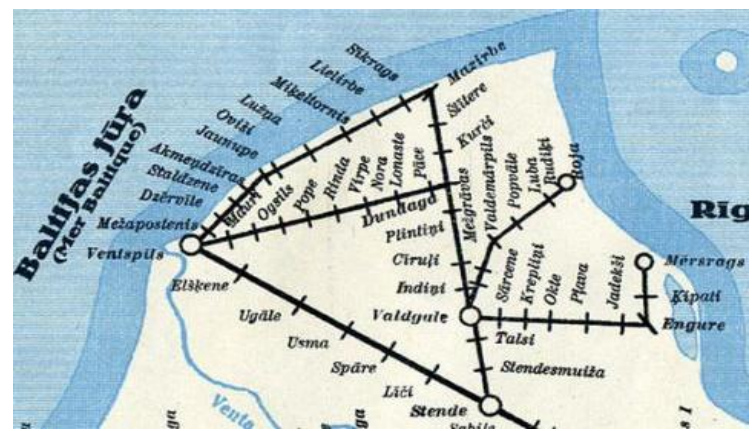

Fig. 3. The dismantled little train track network Stende-Ventspils (1935) [6]

long coastline, providing a certain industrialization of the sector and a better catch,"this region is the place to catch most of our sprats. Naturally, other fish is also much caught there like flounder and herring, also smelt, whitefish, although less"[1]. In the department of the cooperative, there could be common drying rooms, such as the department of Mazirbe where in two drying rooms it was possible to daily "dry around 300000 herrings" [2]. The icefree edge of the sea provided maintenance of a continuous production process throughout the year.

The position of the seaside villages at certain points is not accidental as it is based on the concentration of fish in known places. Going fishing from generation to generation, the deep sea was recognized, where catches were the richest with flounder, herring or sprats. For instance, the best place for the flounder was Lūžna. That's why, in the early $20^{\text {th }}$ century, the number of fishermen dwelling places was very large 38 homesteads [9], where currently only one homestead is left (Fig. 1, 2, 4).

The landscape space of each village has different characteristics of the natural site where the buildings are located in woodland, seaside meadow or slightly rugged nature of places.

The economic trends of fishermen's villages were featured by 4 main landscape spaces, which between themselves created parallelism to the shore:

- the coastline with the fishing net drying on stacks and the sea boat plank-way, leading from the dunes across the beach and the shallow place;

- the dune area that served as a wind barrier for places of dwelling;

- the building zone, where together or in a small distance, fishermen's homesteads are located with a $2 \mathrm{~m}$ wide entrance, leading from the dunes to the homestead;

- behind the building - a forest or cleared land for the fields and pastures.

In the early $20^{\text {th }}$ century, the intensive economic movement was also featured, along with fishing logging, lumber, firewood felling, and trade, since it was sometimes more profitable and gave significant contributions to the farm life. "Mazirbe is located in the farthest corner of the narrow-gauge railway to 


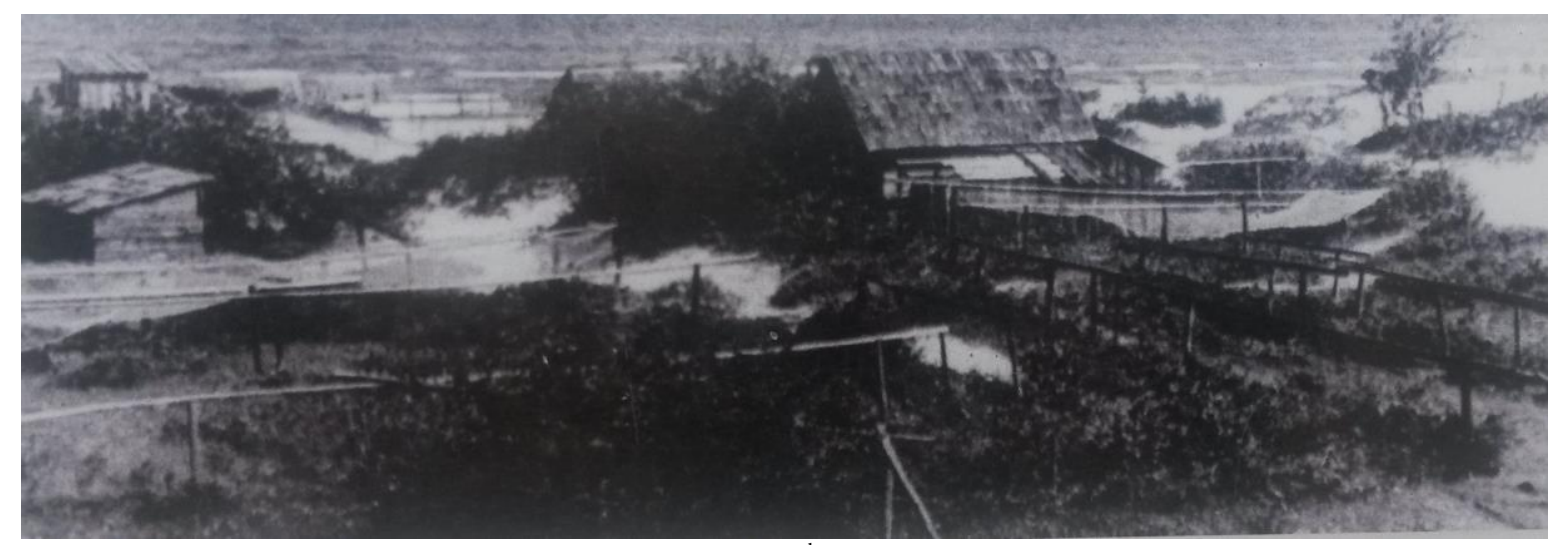

Fig. 4. Barns of the nets in the seashore 30s of the $20^{\text {th }}$ century [Source: Seaside Museum of Ventspils]

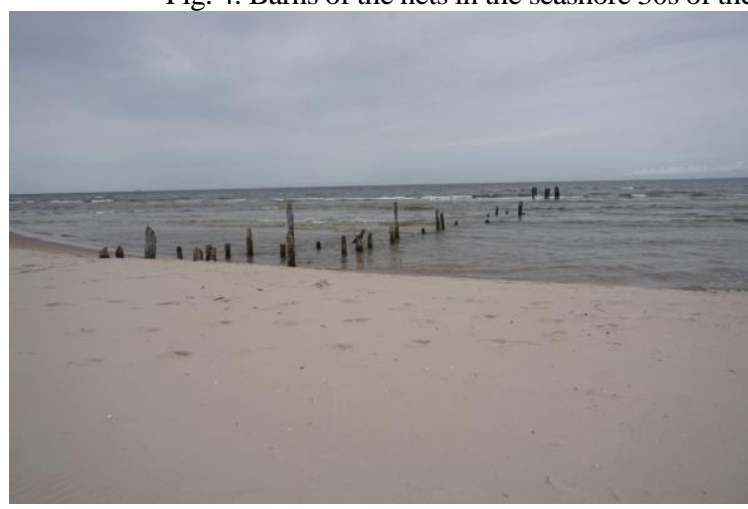

Fig. 5. The boat docks at Mazirbe [Source: photo by authors, 2017]

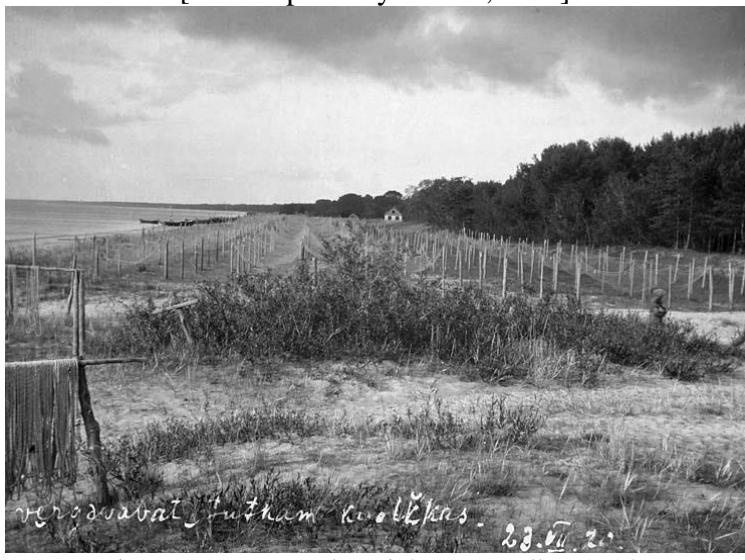

Fig. 6. Net on wooden pickets at Kolka (1920)

[Source: http://www.nba.fi/liivilaiset/Latvia/144/20La.html]

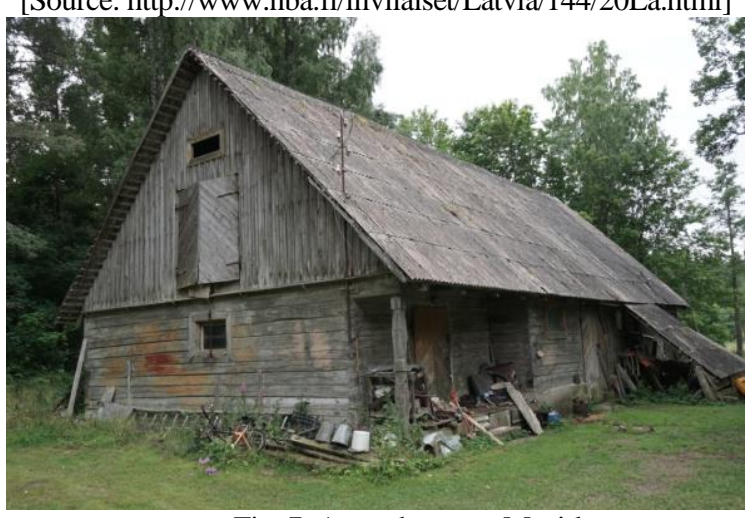

Fig. 7. An outhouse at Mazirbe

[Source: photo by authors 2017]

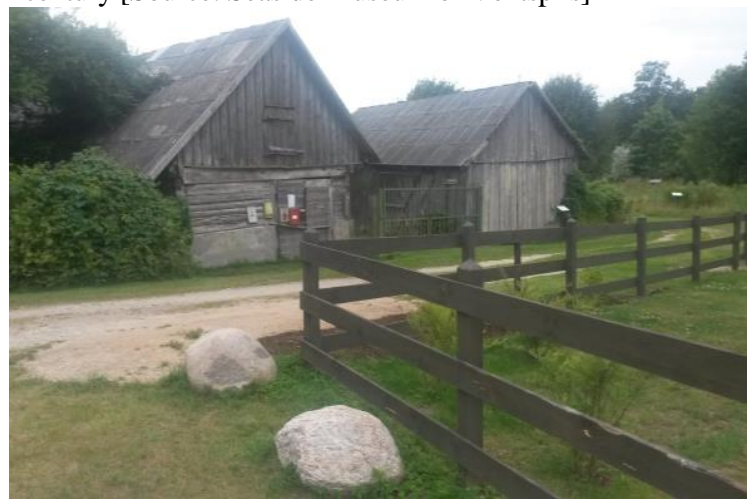

Fig. 8. A fishing net barns at Sīkrags

[Source: photo by authors 2017]

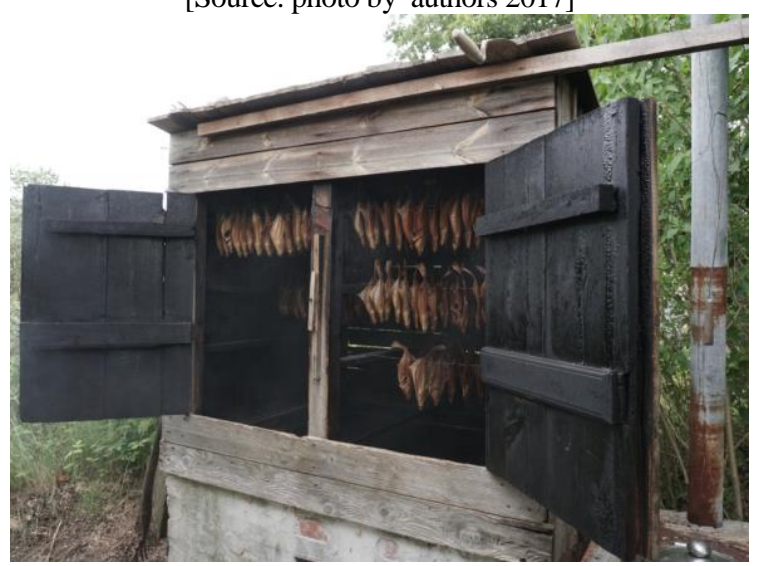

Fig. 9. Fish smoking at Mazirbe

[Source: photo by authors 2017]

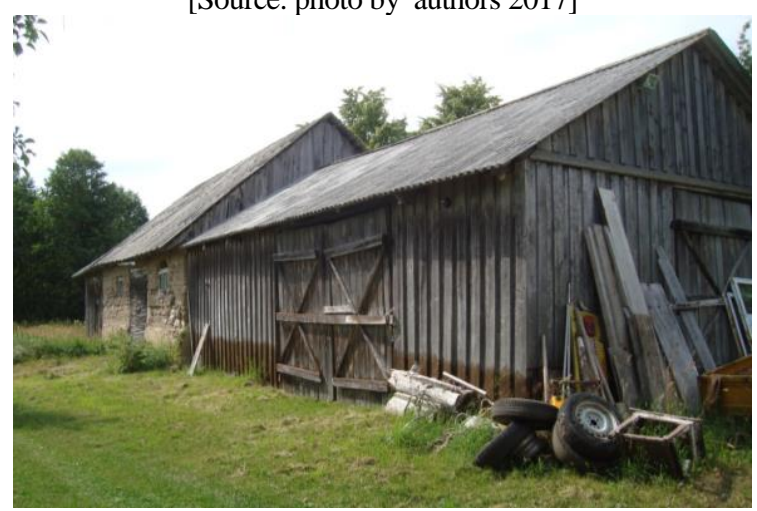

Fig. 10. Cattle-shed and a barn at Sīkrags

[Source: photo by authors 2017] 


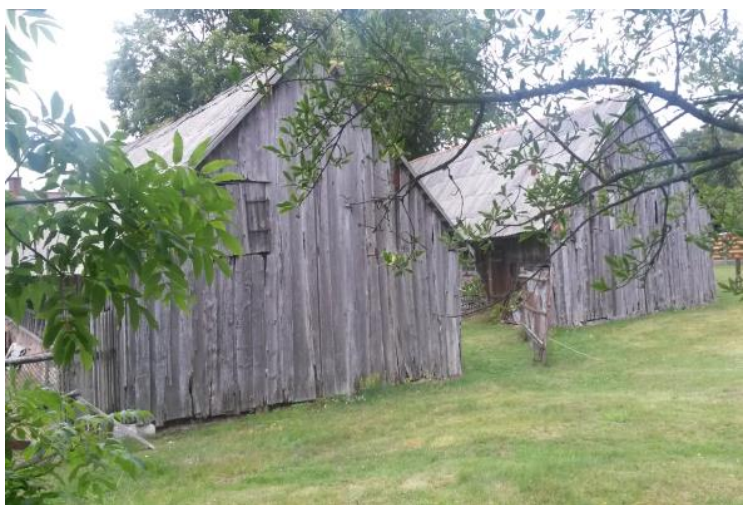

Fig. 11. Barns of the fishermen's homestead at Staldzene [Source: photo by authors 2017]

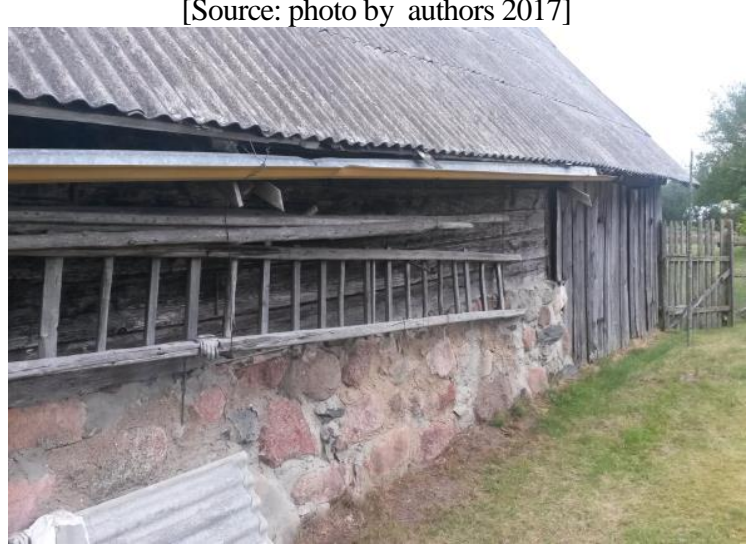

Fig. 12. Deep cattle shed at Sĩkrags [Source: photo by authors 2017]

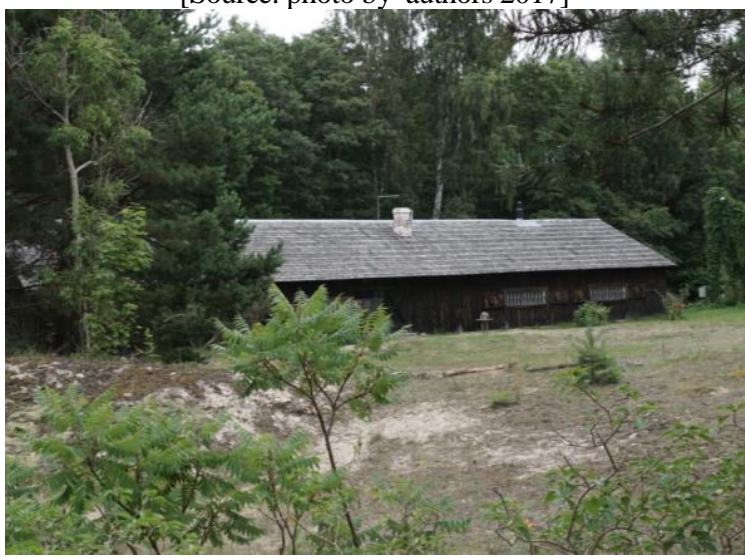

Fig. 13. Fishing net shed at Mazirbe

[Source: photo by authors 2017]

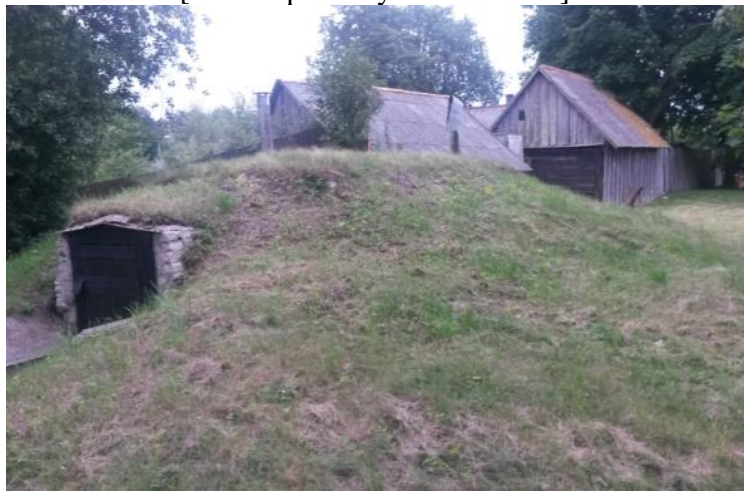

Fig. 14. Cellar and barns at Staldzene

[Source: photo by authors 2017] the north. From here, on both sides, the railway bends back along the seaside to Ventspils, in the middle of the land through the forests and Dundaga, Talsi, Stende. This corner of the railway has a big role due to the large forests of Cape Kolka. And the folks of Mazirbe say that in the forest they are earning more than the land and fishing can give them. They fell, carry, and load in wagons" [3].

The homesteads are distinctive by the location of the building in a flat place. On the slopes, fish and vegetable cellars were installed. At the fishermen's homestead, there was a dwelling house, barns for hay, the boat and fishing nets, firewood, a smoke house, a cattle-shed, a well, which grouped around a wide inner yard. Similarly, as the peasants managed domestic farming, the dwelling house was aside of the cattle-shed in the fishermen's homesteads as well, so that the sea wind could not bring the smells of the cattleshed in the living place.

The dwelling house was made of wood with a shingle roof, usually of wooden stands, cladding the exterior wall with horizontally placed boards. Between the foundation and the windowsill line boards were frequently placed vertically, keeping such belt between the beam and the wall plate place as well. Cattle-sheds were built from logs or wooden stands, basing them on a high stone foundation, forming the so-called deep cattle-sheds. Along the stone foundation, the manure was kept inside during the winter so that with the start of grazing to leave them on the field. Barns served for keeping the wood, hay, boats, and fishing nets (Fig. 5, 6). They are wooden with vertical boards, based on a small stone foundation. As one of the typical colorings is the black tone, historically using the wood tar. When boats were tarred, the exterior walls of buildings were also tarred.

For the homesteads that were located nearer to the dunes, the longest side of the barn was built parallel to the sea shore to get less wind in the yard. Two adjacently placed barns with the long sides are also visible, where the outside barn protects the inner side barn from gusts of the wind (Staldzene, the two parallel barns at Sìkrags).

In the early $20^{\text {th }}$ century, the old boats mounted vertically were adapted to fish smokehouses. This peculiar application creates the language of form creation, which describes the Liv villages.

\section{Results and Discussion}

After the collection of the archival materials, the information obtained with the comparison method is used during the expedition (July 2017).

Researching the transformation processes and summarizing the effect of the social and political 
features on the cultural and historical territory, they are broken down into 3 main defining criteria:

- the change of the ethnic identity, brightly characterized in the monograph, "Still in the middle of the $19^{\text {th }}$ century, the northern coast of Kurzeme was inhabited by only the Livonians (Livs). They referred to themselves as "rāndalist" - the coast dwellers. At Jaunciems, Mazirbe, Košrage, Pitrage, Saunags, Kolka, and Melnsils, only the Livonian language was heard. Latvian was spoken on the "hill" - above the Slitere Blue Hill bluffs, away from the sea. The Latvians tended livestock, the Livs were mostly engaged in fishing, as the coastal soil was sandy and lean. In 1810, in the above mentioned Livonian villages, there were almost 500 sea fishing boats. The whole fleet! And in every village, there was at least one "koploja" - a large trade boat for longer journeys. Firewood and other goods were transported even to St. Petersburg. The Livs also worked as commercial intermediaries, for instance, on the "hill" purchased honey and wax to favorably sell it in Riga. It is not surprising that "randalisti" were more prosperous than the Latvians" [7].

- the economic identity;

The last 100 years in the development of the coastal villages reached the culmination of development and misery, performing a destructively painful somersault. The unique cultural landscape is irretrievably lost, only rare witnesses are left behind about the presence of the fishery on this sea coast. In the early $20^{\text {th }}$ century, the homesteads actively involved in fishing with the provision of the sector-specific buildings, farm tools and equipment, including the fishing net drying on the stacks in the dunes, boat docks on the sea coast, which generally created a highly unique, distinctive cultural landscape of the fishermen's villages and lively environment.

- The development of tourism infrastructure in the early $21^{\text {st }}$ century.

By the data collected, in the $30 \mathrm{~s}$ of the $20^{\text {th }}$ century, it is possible to compare the number of the fishermen's homesteads; Lūžna -38 , today - 1 [9]; Miḳeḷbāka - 55 homesteads, today 7 [9]; Jaunciems - 17 houses and a number of motorboats [9].

Mazirbe - a Livonian center where in 1937 there were 249 residents and 50 of them spoke in the Livonian language. The starting point of converting into the Latvians.

In the village, there is the railway station, an elementary school, the district doctor, the post and telegraph office, a ranger, a steam mill with a sawmill, a brickyard, a pharmacy, some outlets, the Lutheran Church, a pastor, and 256 residents" [4].

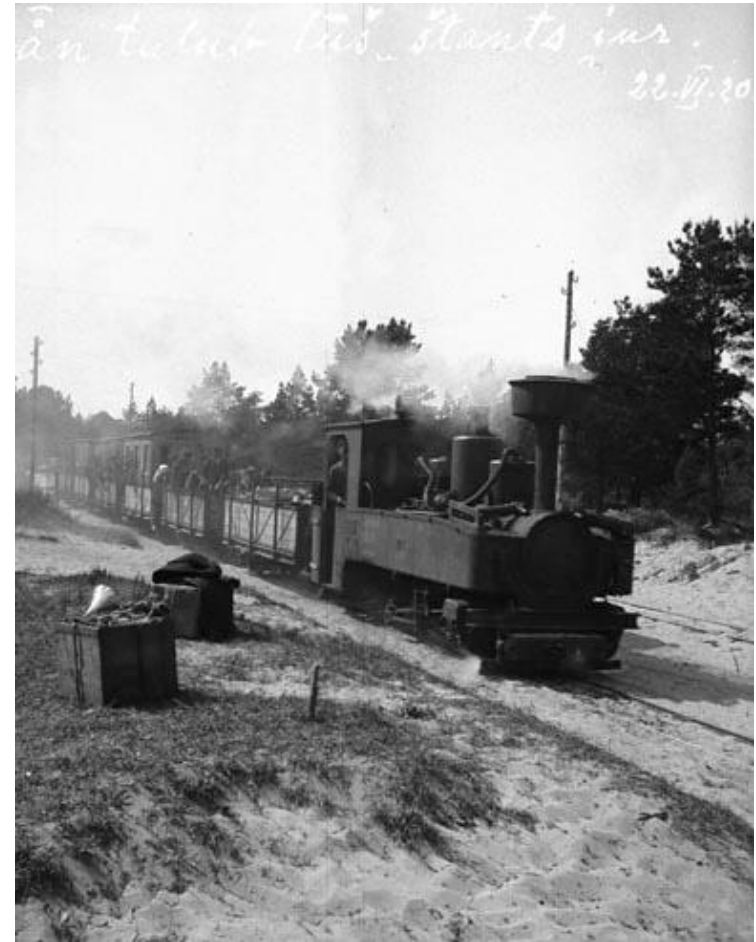

Fig. 15. Little train, 1920. g.

[Source: http://www.nba.fi/liivilaiset/Latvia/144/007La.html]

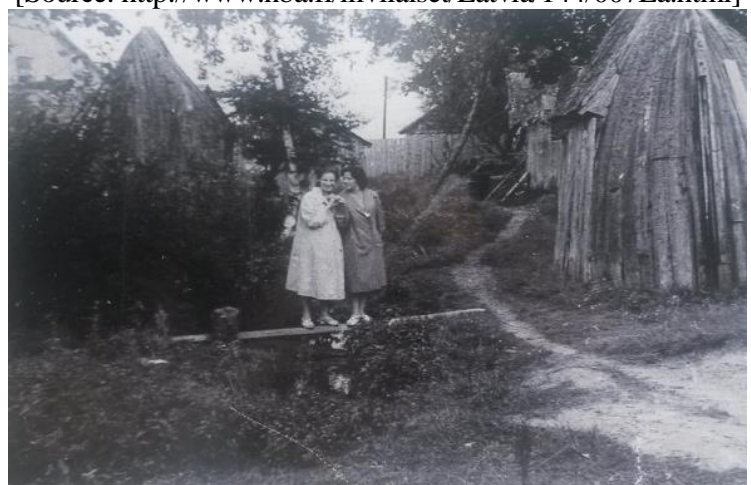

Fig. 16. Old boats as drying house

[Source: photo by V. Dzene]

Lielirbe - 60 houses, 5 phones, 20 and more different boats, fishing net huts in the dunes, two or three lead ropes, lamprey weirs.

Sīkrags - in documents as a village mentioned already in 1387 . During the $17^{\text {th }}-18^{\text {th }}$ centuries, one of the most significant small ports on the northern coast of Kurzeme [9].

Košrags - 110 residents, of which 10 fishermen, a motorboat, an open-sea boat, a jetty.

Founded in the $17^{\text {th }}$ century and even in 1680 as the only homestead in Košrags - the homestead "Kūkiņi" is mentioned. In 1826, at Košrags there were 78 residents; in 1932, the construction of the port was organized, in 1938, a jetty for the collection of mud (sea manure) [5].

Pitrags - in historical sources is first mentioned in 1582 . In the middle of the $19^{\text {th }}$ century, a pub was opened at Pitrags. In the early $20^{\text {th }}$ century 12 farms which have belonged to generations of 
farmers, 38 fishermen's holdings, 2 motorboats, several sailing boats, many row boats. It was intended (around 1938) to build a fishermen's shelter port in the estuary of the river at Pitrags.

In the $19-20^{\text {th }}$ centuries, Pitrags was known as a major boating and shipbuilding center, which essentially contributed to the socioeconomic development of not only the village but also of all the sea coast. In the Soviet times, a fish-smoking factory was built at Pitrags.

Saunags - in the historical sources for the first time mentioned in 1310. In 1826, in each homestead, there were 16-17 people, together around 60 people. In 1938 - 5 motorboats, 3 sprat salting tubs. Vaide - in 1935, 106 people lived there. Nowadays, the development of the Liv coast is affected by several factors:

1.The fishing industry in Latvia, since joining the European Union, is regulated by the set fishing quotas in fishery and the Fishery Law (in force since May 12, 1995). Unfortunately, the rapid reduction of fish resources in the Baltic Sea and the fishing quotas set by the European Union do not sufficiently provide the fishermen with work and income, thus not contributing to renewing of the fishery-related cultural landscape on the Livonian coast.

2.The benefit in the sphere of nature protection is positively celebrated - the silenced economic activities and the closed, military regime of the area in the Soviet years allowed to maintain relatively intact natural environment to the present days and around 860 different species of rare plants, the diversity of which was formed due to the particularly mild climate of North Kurzeme, for instance, the yew and the Baltic ivy.

3. The dismantled little train track network and most of the railway stations are thelost opportunity for the tourism industry. The maximum total length of the railway during its existence (1916-1963) reached 280 kilometers. Later, the little train lines were also used for the carriage of passengers and for a long time it was the only means of traffic along the seaside villages of Kurzeme.

\section{Conclusions}

The farming culture of the $14^{\text {th }}$ century brought by the Livonians at the seaside has given a great contribution to the cultural and historical heritage of North Kurzeme up to the early $20^{\text {th }}$ century. Its uniqueness is based on the historic nature of farming and the structure of farm building, which was the subject of both the natural area and farming peculiarities.

Thanks to the modern strict legislation for determining the threshold of the criteria in architecture and construction in the Slitere reserve, the start of restoration of the homesteads of the historic coastal building is noticeable in the last ten years. This applies not only to the dwelling houses but also to the historical identity searches of the old outhouses, the fence, and the inner yard area. As the next step at the municipal level is to be mentioned the amount of work for the recovery of the historical functional identity of the coastal landscape space - fishing net huts, fishing net drying on stakes, wooden docks. By starting the restoration of the old elements of the fishermen's farming environment on the sea coast and in the fishermen's homestead building, the started restoration work of fishermen's homesteads would be continued. It is not sufficient to base the revival of the historical landscape space only on the funding opportunities of private operators. It requires a serious financial support of the program developed by national institutions.

As it is previously mentioned, in the $21^{\text {st }}$ century, the new mansion building in the village of fishermen, identical in the historical scale and coloring, can recover identity to attract tourism infrastructure in North Kurzeme. The collected materials of the research are the starting point of the architectural form creation and the understanding of the compositional language of the building in recovering the historic area.

\section{References}

1. Dubiňš, E. Kurzemē. 1993. g., Rīga: Preses nams, 1993., pp. 100.-101.

2. Dubiṇš, E. Kurzemēe. 1993. g., Rīga: Preses nams, p. 98.

3. Dubiņš, E. Kurzemē. 1993. g., Rīga: Preses nams, p. 97.

4. Dubiṇš, E. Kurzemēe. 1993. g., Rīga: Preses nams, p. 96.

5. Kurzeme. Rīga: Latvijas enciklopēdija,1993., pp. 86-89.

6. https://lv.wikipedia.org/wiki/Stendes\%E2\%80\%94Ventspils_lauku_dzelzce\%C4\%BCi

7. Pope, A. Burinieku gadsimts Latvijā. Rīga: Zinātne,1989., pp. 21.-22.

8. Šuvcāne, V. M. Mazirbe - mazs ciems Jürmalā. Rīga: Jumava, 2006., p. 164

9. Šuvcāne, V. M. Lībiešu ciems, kura vairs nav. Rīga: Jumava, 2002., p. 490.

\section{INFORMATION ABOUT AUTHORS:}

Dace Ržepicka. Mg.arch., phD Student in Latvia University of Agriculture, Research on the industrial heritage of the Baltic Sea coast. E-mail: dace.rzepicka@inbox.lv

Aija Ziemeḷniece. Dr.arch. A. Ziemelniece is an prof. in Latvia University of Agriculture, specialized in fields cultural heritage, Study of transformation processes of rural landscape. E-mail: aija@k-projekts.lv 
Kopsavilkums. 14. gs. lībiešu nestā saimniekošanas kultūra piekrastē līdz 20. gs. sāk. ir devusi spēcīgu kultūrvēsturisko mantojumu Ziemeḷkurzemei. Tās savdabības pamatā ir vēsturiskais saimniekošanas raksturs un sētu apbūves struktūra, kas bija pakḷauta gan dabas pamatnes, gan saimniekošanas īpatnībām. Zvejnieku sētas kā atseviškas nelielas dzīves telpas reizē kalpoja kā "ražošanas zonas", apstrādājot zivis, būvējot laivas, sagatavojot zāğmateriālus, aužot tīklus. Minētais veicināja vienlaidus "ražošanas" teritorijas izveidošanos gar piekrasti, kas īpašu uzplaukumu ieguva 20. gs. 20.-30. gados. Pamazām attīstoties amata prasmei airu laivu izgatavošanā, pieauga gan to skaits, gan nozvejas daudzums, gan labu zvejas vietu atpazišana. Kopumā tas veicināja aizvien blīvāku zvejnieku sētu novietojumu vienkopus. Zvejniecības specifikas pamatā ir smagi fiziskā darba apstākḷi, ko nav iespējams veikt vienam - viḷnos noturēt līdzeni laivu, izmest un izcelt tīklus vai vadu un airēt. Šim darbam ir nepieciešami vairāki vīri, kas vienlaikus varēja doties jūrā. Zvejas darba specifika labi atspogulojas ciemu apbūves kompozicionālā uzbūvē - blīva apbūve ar tīklu būdu novietojumu liedagā un aiz kāpām, vairāku šķūṇu novietojums sētas pagalmā paralēli, kuriem cieši garām ved ceḷš pāri kāpām. Kūts vai šķūņu jumtu slīpnes, to augstums, šķūnu platums un to distancējums tika ievērtēts, zinot valdošā vēja virzienu un aizvēja vietas, pagalma lielumu, zivju žāvēšanas būdu novietošanas vietas, cel̦š no kūts uz ganībām, ledus pagrabs kāpas nogāzē utt.

Pētot transformācijas procesus un apkopojot sociālo un politisko iezīmju ietekmi uz kultūrvēsturisko teritoriju, ir iedalāmi vairāki situāciju raksturojošie pamatkritēriji: valsts politiskā nostādne, etniskās identitātes maiņa, saimniekošanas tradīcijas, tūrisma infrastruktūras attīstība 21. gs. sāk.

Lībiešu piekrastes kultūrvēsturiskās saimniekošanas atgūšanu mūsdienās ietekmē vairāki faktori:

1. Zvejniecības nozari Latvijāa kopš iestāšanās Eiropas Savienībā, reglamentē zvejniecībā noteiktās nozvejas kvotas un Zvejniecības likums (spēkā kopš 1995. g. 12. maija). Zivju resursu straujā samazināšanās Baltijas jūrā un Eiropas Savienībā noteiktās nozvejas kvotas, kas, diemžēl, nepietiekami nodrošina zvejniekus ar darbu un ienākumiem, tādējādi neveicina ar zvejniecību saistītās vēsturiskās kultūrainavas atjaunošanos lībiešu krastā.

2. Dabas aizsardzības prasības - apklusinātā saimnieciskā darbība un teritorijas noslēgtais, militārais režīms padomju gados ḷāvis saglabāt līdz mūsdienām salīdzinoši neskartu dabas vidi, un ap 860 dažādas reto augu sugas, kuru daudzveidība izveidojusies pateicoties Ziemeḷkurzemes īpaši maigajam klimatam, piemēram, parastā īve un Baltijas efeja.

3. Kā pazaudēta iespēja tūrisma nozarei ir demontētais mazbānīša sliežu tīkls un lielākā daḷa dzelzceḷa staciju, kas vēsturiski kalpoja zvejnieku saimnieciskās dzīves uzturēšanai.

Pateicoties mūsdienu aizsāktajai stingrai likumdošanai arhitektūras un būvniecības kritēriju noteikšanai Slīteres rezervātā, ir pamanāms pēdējo desmit gadu laikā veco piekrastes zvejnieku sētu atjaunošanas aizsākums. Tas ir attiecināms ne vien uz dz̄̄vojamo ēku, bet arī uz veco saimniecības ēku, žoga un iekšpagalma teritorijas vēsturiskās identitātes meklējumiem. Kā nākošais solis pašvaldības līmenī ir minams aizsākums krasta ainavtelpas vēsturiski funkcionālās identitātes atgūšanai - tīklu būdas, tīklu žāvējamās vabas, koka steḳi. Tam ir nepieciešams nopietns valsts institūciju izstrādātas programmas finansiālais atbalsts. 